\title{
Judicialization of Catalonian Language and Identity Politics
}

\author{
Walter F. Carnota \\ Universidad de Buenos Aires, Buenos Aires, Argentina
}

\begin{abstract}
Since the adoption of the 1978 Spanish Constitution, the relationship between the Spanish State and the Catalonian autonomous region has been considerably strained. Originally, many remembered the dictatorship of Francisco Franco (1936-1975), when centralization was heavily imposed on all parts of the country, irrespectively of ethnicity, language or traditions. As the constitutional bargain (Title VIII of the 1978 Constitution) worked for smaller regions (Madrid) or poorer regions (Extremadura), it did not pan out for an economic powerhouse as Catalonia. For over 30 years, Catalonian regional political parties (notably Convergencia e Unio) have held the balance of power within the Spanish parliamentary system. Autonomous regions were allowed to write their own "statutes", a sort of sub-national constitution subject to national approval. Anti-Spanish sentiment is running high in Catalonia, and a straw poll was conducted in 2014, as voters were asked if they wanted to remain part of the Spanish kingdom. Many Catalonians would sever all ties with Madrid while attempting to remain in the European Union, a move preemptively vetoed by the European Commission. Inevitably, more judicialization is expected, whether on a federal scenario (intergovernmental relations: who does what) or if secession ultimately happens and economic compensation becomes necessary. The ruling Popular Party is adamant to any concessions; left-wing parties are more open to nationalistic demands. But the strictly political negotiations between the Popular party and the Socialists (who favor federalism) are stalled and nationalism is being overplayed by regional forces. As political solutions seem to falter momentarily, Courts will experience more demands based on identity grounds.
\end{abstract}

Keywords: Spain, Catalonia, independence, constitutional design, European integration

\section{Introduction}

The Spanish national Constitution celebrated its 35th anniversary in late 2013. During its three and a half decades, the Constitution provided Spain with the necessary stability to transition peacefully from the Franco era dictatorship to become a full-fledged member in 1986 of the then European Economic Community (now the EU). Although partisan bickering is pretty common between the two major political forces, the Popular Party (PP) and the Socialists (PSOE), parliamentary monarchy under former King Juan Carlos enabled the country to achieve minimum consensus on democratic governance, dismantling the previous centralized state (García Morales \& Arbós Marín, 2010, p. 44) and upholding the rule of law, even in the midst of the severe 2010 economic crisis (Rodríguez Zapatero, 2013).

Political decentralization sketched by the Constitution remained an unfinished business, a thorny issue to be redefined later on by political means. The first decades of the new cycle were signaled by Basque terrorism spearheaded by ETA, despite the overall success of the constitutional design of parliamentary monarchy. Lately, ETA has renounced its violent means and the ECtHR in October 2013 enabled prominent terrorists to

Walter F. Carnota, Ph.D., Law School, Universidad de Buenos Aires. 
be sent home from jail, tossing away the so-called "Parot doctrine" concocted by the Spanish courts. ETA is currently in a cumbersome process of giving up its weaponry and accepting the democratic political process.

Now that Basque separatism has ebbed considerably, Catalonia-Spain's most vibrant economy-threatens with independence. First, it scheduled a referendum for November 9, 2014, based on two questions: (1) Is Catalonia a state? (2) Should it be independent? Catalonian leading political coalition CiU (Convergencia e Unió) and other regional parties such as ERC aggressively promoted a "yes" answer to both questions on the ballot, based on the premise that Catalonia was entitled to "decide to decide" (a local version of the right to self-determination) and paving in this fashion the way for outright independence from Spain (the so-called "soberanismo", meaning the position which defends the "sovereign rights of Catalan people"). The Catalonian Executive headed by Artur Mas conducted a highly visible international campaign (mainly within the EU and even the U.S.), so as to elicit eventual support from the international community.

The Spanish central government in Madrid, in turn, coordinated policy with the British government of Prime Minister David Cameron in order to link Catalonia with other parallel situations such as that of Scotland (which held a referendum on September 16, 2014, when independence from the UK lost). In sum, the pro-independence forces dislike Catalonia's current status ("encaje") within Spain; they would gleefully retain EU membership, despite qualms from Brussels as to how to achieve this goal. Catalonia is part now of the EU because it is a portion of Spain: how an independent Catalonia could retain this status in the future remains an open question.

Spanish majority parties have different stances towards Catalonia. The current PP government flatly denies any right to regional self-determination without explicit approval from the national Parliament (Cortes). The opposing PSOE is prone to the adoption of a federal model, replacing the instability of autonomous communities for good.

Regionalism has been a key component of Spanish party politics, as PNV in the Basque country and CiU in Catalonia eloquently illustrate. As Hamann (1999) observed,

Compounded representation is a crucial concept in understanding the development of patterns of political representation in Spain. The existence of regional administrative and political units, including regional parliaments and executives, provides a strong incentive for regional parties to form and compete in regional elections, as well as in national and European elections, by emphasizing the distinct interests of the voters in that particular region. (p. 112)

Why did this particular conflict begin to flare up again? Catalonia strongly supported the democratic transition from Franco and its final outcome the 1978 Constitution, which was only resisted by Basque nationalists (Peces-Barba Martínez, 1988, p. 252). The "territorial model" adopted by Title VIII of the Constitution was a unitary decentralized hybrid called "Estado de las autonomías" or "state of autonomies" (Aja, 2014, p. 16)

Authority is vested mainly on the central government; however, a significant number of tasks may be performed by CUs (constituent units) autonomously. Yet, the judicial decision of June, 2010, invalidating some parts of Catalonia's new sub-national constitution (EAC) fueled the flames of the current conflict. Catalan people saw the ruling as a response to "a political climate that it is widespread in Spain in which one of the objectives is to put an end to the development of regional autonomy" (Cardús, 2011, p. 26).

The Spanish Constitutional Court twice became involved in the Catalonian question during 2014. First, it ruled that the Nov. 9 referendum as such was unconstitutional since it was not called under the aegis of the 
national Constitution. Subsequently, it also suspended on Nov. 4, 2014 a diluted version of the referendum (a so-called "participation process" election). Anyway, people voted on November 9 as scheduled in the straw poll format, where as expected pro-independence forces won.

\section{Historical and Sociological Context}

Catalonian grievances date back from 1714, when the Spanish Succession War ended and Bourbonic rule suppressed Catalonian freedoms ("Decreto de Nueva Planta"). From that moment on, Spain and Catalonia faced diverse development and social paths. Catalonia remained an integral part of Spain, but disputes lingered on. Centralism was rampant in the 19th century and first seven decades of the 1900s.

Internal migrations fostered the widespread use of the Spanish language in the 1800s. Catalan was mainly confined to rural areas and became a secondary language of sorts. Linguistic imperialism took hold: major newspapers in the capital city of Barcelona (such as "La Vanguardia", for example) were published in Spanish, instead of Catalan.

John E. Joseph (2006) further observed that:

Catalonia was the center of the left-wing movement that briefly established an anarco-syndicalist government in the region in 1936, and it continued to be the center of resistance to the Franco government over the following decades. For Madrid, the suppression of the Catalan language thus had a clear political-symbolic motivation. For Catalans, in turn, the laws forbidding the use of the Catalan language made it the symbol for all their political and cultural aspirations. Retaining their language, using it despite the laws forbidding it, was a political and cultural imperative. Catalan attained its symbolic force from its suppression by the "other" power. (p. 40)

Catalonia's relationship with the centralist Franco government (1936-1975) was confrontational. Boix (2011) added that:

Our current problem... started in the 1950s, when large-scale Spanish immigration doubled Catalonia's population. It was a time when all the practical mechanisms for promoting functional assimilation were outlawed by the Franco government. From the start, the regime was brutal in its repression of the Catalan language...In the 50s and $60 \mathrm{~s}$, the situation was made even worse by radio and television, which were exclusively in Spanish and were absolutely Spanish in content and ideology. (p. 22)

Catalonia endorsed the new constitutional framework of 1978, which was put in place after Franco had died in 1975. But the most recent focal point of discussion involved a highly controversial judicial decision (STC 31/10). The Spanish Constitutional Court in 2010 struck down as unconstitutional certain key provisions of the Estatut d'Catalunya (Catalonia's de facto sub-national constitution ${ }^{1}$ ). This step was seen by many in Catalonia as another evidence of the supremacist stance of the Spanish state over historic regions and rights.

\section{Constitutional Framework}

The autonomous state is a rather vague idea. It was purportedly devised as a work in progress, an initially open-ended model prone to subsequent fine-tuning and flexible scenarios (Díaz Ricci, 2009, p. 87; Villaverde Menéndez, 2012, p. 76). Some authors even labeled it as a "never-ending federal state" (Valdés, 2001, p. 163), to emphasize that it involves a process rather than a finished product. To compound the problem, Article 2 of the Spanish Constitution contains two joint principles which could eventually collide: indivisible unity of the

\footnotetext{
${ }^{1}$ Ironically, each autonomous community has its Statute, but it is actually enacted by the national Cortes in Madrid as an organic law, a hard proposition for a federal state to swallow.
} 
State and autonomy rights of regions and "nationalities"2.

A constitutional issue develops when individual and social rights are recognized both at the national and sub-national levels, and courts at both levels of government face similar problems. In federal states, this is called "jurisdictional redundancy" (Cover, 1981, p. 639).

Famous scholar Daniel Elazar (1987) pondered that,

$[R]$ edundancy was considered to be one of the unattractive aspects of federalism, something to be tolerated because of federalism's political virtues but minimized whenever possible. This view became especially prevalent after the rise of the modern science of public administration, which is built on hierarchical principles and the notion that the larger the institution or organization, the more efficient it will be. (p. 30)

Spain's Estatutos de Autonomía, like American state constitutions (Gardner, 2007), often duplicate rights recognized at the center (Aparicio, 2008). And the Spanish Constitutional Court had a relevant role in defining the terms of autonomy since its very inception (some even spoke about a "judicial autonomous state", Fernández Ferreres, 2005, p. 17), as the Catalonian Supreme Court also had on a lesser degree (see below). However, the Constitutional Court issued two very important judgments, the first concerning the Valencia Statute $^{3}$ and the second one, most importantly, about the Catalonian Statute (EAC) . $^{4}$

\section{A Most Important Judicial Decision (STC 31/10)}

Judgment 31/2010 proved to be pivotal in the conflict between Spain and Catalonia. Ninety-nine legislators from the-then disgruntled opposition conservative party PP (now in government) ${ }^{5}$ challenged the 2006 reforms to the EAC as unconstitutional ${ }^{6}$. The Constitutional Court partially agreed, holding that fourteen clauses were inconsistent with the Spanish Constitution. Simultaneously, in a long and complex ruling spanning more than 800 print pages (López Aguilar, 2011, p. 224), it also validated many other clauses.

The whole reform process of autonomy statutes was halted. Colino and Olmeda (2012) contended that:

Due to a protracted process of reform and to the final intervention of the Constitutional Court with a landmark ruling on the Statute of Catalonia, this round of reforms has raised many questions about the real reform capacity of the system, on its capacity to achieve integration, accommodation, and adaptation to changing social circumstances and therefore legitimacy and stability without formal constitutional reform. (p. 192)

Firstly, the Court held that the EAC Preamble, replete with references to Catalan nationhood, had no legal effect whatsoever. It also struck down article 6, section 1, which mandated for preferential use of Catalan in public administration, public mass media and education. "Preferential" was deviant from a bilingual policy of equal footing between the Spanish and Catalan languages. Other stricken provisions involved Catalonian powers vis-à-vis the central government in Madrid, which the Constitutional Court is entitled to referee (Biglino, 2007, p. 154).

Are the national and linguistic aspects intertwined? Undoubtedly, yes. Major (2013) stressed that:

\footnotetext{
2 The first principle is relevant as far as constitutional amendments are concerned, since they require a nation-wide will to reform the Constitution (Sánchez Agesta, 1980, p. 344).

3 STC 247/2007.

4 STC 31/2010.

5 The PP had been excluded from the reform deal which was struck between the three-party sub-national Catalonian government and the PSOE-led Administration in Madrid.

${ }^{6}$ These amendments were the first to be made to the 1979 Catalonian Statute. Its text mushroomed from 57 articles to 223 articles, becoming in effect a fully-fledged sub-national Constitution (Castella Andreu, 2010, p. 6).
} 
Catalans are no different from any other society in the world in that their culture has a particular language as its proper vehicle. And, no differently from every other society in the world, they see in their language a central element of their national character. (p. 86)

EAC Preamble references to nationhood ("Catalonia is a nation", "national reality of Catalonia") are deliciously vague and not prone to a straightforward constitutional interpretation. It is not easy to tell, for example, whether they fall inside or out of the Article 2 perimeter. Several times the Catalonian Legislature ("Parlament") had issued unilateral nationhood declarations (1989, "Catalonia is a differentiated national reality which does not resign its right to self-determination"; 1998, It confirms the right of the Catalan people to freely choose its future), but the nationalist references were now entrenched in the EAC).

Judicially, the Catalonian Executive argued in briefs that the Constitutional Court had given no legal effects to preambles in prior decisions ${ }^{7}$, so nationhood as it stood was a mere political statement with no binding legal character. The Court, however, disagreed: it held that Preambles had no dispositive effects as legal norms regularly do, but that they still represent useful yardsticks for constitutional interpretation (Solózabal Echavarría, 2011, p. 216), according to its own criteria espoused in STC 36/81. Consequently, Preambles were not entirely "off-limits" to some kind of judicial scrutiny.

The Constitutional Court was bent on defusing EAC's own imprint as a whole sub-national Constitution. Many Constitutions worldwide have preambles and they serve as helpful tools to sharpen constitutional identity. ${ }^{8}$ The Court wanted to send a clear message to Barcelona, in the sense that nationhood was ambiguous and that it did not entertain the idea that a distinct citizenship (i.e., a political concept) could be derived from a cultural or social reality. Technically, it did not strike down the Preamble as unconstitutional, but it gave it no effect as far as nationhood was concerned. Undoubtedly, it was a big blow to Catalan identity politics. Salvador Cardús sums it up (2013):

Awareness of the complete failure of the [reform] project, which began in 2006, was widespread by 2010. The Catalonian people leapfrogged the political class by demanding a new sovereigntist political framework. The final denouement arrived with the demonstration in September 11, 2012, the day that Catalonia celebrates its National Day. (p. 98)

Former Catalonian President Jordi Pujol-himself a recent subject of criminal investigation due to money transfers to Andorra- has termed the ruling as "harmful" and "morally damaging" (2011, p. 59).

\section{Language Politics in Court}

One of the most delicate areas of identity politics is language. Language permeates everyday life and almost every identity politics equation (Canada, Belgium) has had linguistic implications as a substantial part of it.

STC 31/10 also meddled in language politics. Its criticism of Catalonian identity politics did not stop at nationhood or national reality. One of the most visible consequences of national affirmation is language, and it has a reverse effect on national politics: A common language (English in Canada) is heightened and the minority/majority language (French in Québec) seems to suffer. The same happens with Spanish and Catalan, even though Spanish is also the first language in Catalonia (a rough 36\%-51\% ratio currently exists).

\footnotetext{
7 STC $36 / 81$ at paras. 2 and 7.

8 With the exception of the Netherlands, Austria, Uruguay and Chile Constitutions, among other countries, which do not include Preambles.
} 
The 2006 EAC had provided for a language policy bent on a preferential treatment of Catalan so as to bolster national identity. It was not a new stand: previous sub-national legislation on language use had a manifest pro-Catalan bias.

Recently, Catalonia's top Court has ruled in favor of a $25 \%$ use of Spanish in five schools as "lengua vehicular" (lingua franca). Many object to a fixed percentage determined by courts.

Catalonia has pursued a policy of linguistic immersion, where Catalan is prevalent and Spanish remains a secondary option, having to make room for other languages such as English. Controversies abound, since business and commerce with the rest of the country is obviously conducted in Spanish and internationally in English. Increasing globalization has compounded the linguistic issue:

In our globalizing world, the distinction associated with geography, including statehood and language differences, are fading as English becomes ubiquitous and even nation states that have not restructured officially are dealing with non-national normative claims, entailing legal changes of a non-national nature (Grosswald Curran, 2006, p. 700)

STC 31/10 objects to Article 6.1 of EAC which gives preference to Catalan. The Court states that preference is not just an empirical observation such as "linguistic normalcy". If Spanish and Catalan are on an equal footing "official language" status, it would seem contradictory to upgrade one of them to a preferential rank. In that case, the "equilibrium" among the two official languages would be affected.

\section{Future Trends}

It seems, after the 9-N voting, that the Spanish government and its top Court would not be able to catalog Catalonia's claims as "illegal" forever". At some point, negotiations between Madrid and Barcelona should start in earnest, paving for a "third way" or a nuanced version of regionalism. The Socialist Party continues to vouch for a federal option; the new party Podemos is eager to pursue a "Scottish solution", meaning more dialogue and consensual solutions. Gridlock is for the moment gaining the upper hand.

Catalans are keen to continue as EU members, despite some formal objections from the European Commission. Some contend that were Catalonia leave the Spanish state altogether, it would have to reapply for admission to be fully approved by the 28 Member States. Probably, this issue will end up at the ECJ sitting in Luxembourg, which would imply a new round of judicialization.

\section{References}

Aja, E. (2014). Estado Autonómico y Reforma Federal. Alianza, Madrid.

Aparicio, M. (Ed.). (2008). Derechos y Princípios Rectores en los Estatutos de Autonomia. Atelier: Barcelona.

Biglino, C. P. (2007). Federalismo de integración y de devolución: el debate sobre la competencia. Madrid, Centro de Estudios Políticos y Constitucionales.

Boix, C. (2011). Interview. In T. Strubell (Ed.), What catalans want (“Could Catalonia become Europe's next State”). Ashfield, Mass, Catalonia Press.

Cardús, S. (2011). Interview. In T. Strubell (Ed.), What catalans want ('Could Catalonia become Europe's next State’). Ashfield, Mass, Catalonia Press.

Cardús, S. (2013). What happened to us Catalans? In L. Castro (Ed.), What's up with Catalonia (The causes which impel them to the separation). Ashfield, Mass, Catalonia Press.

Castella Andreú, J. M. (2010). La sentencia del Tribunal Constitucional 31/2010, sobre el Estatuto de Autonomía de Cataluña y su significado para el futuro autonómico. Fundación Ciudadanía y Valores.

Colino, C., \& Olmeda, J. A. (2012). The limits of flexibility for constitutional change and the uses of sub-national constitutional

\footnotetext{
${ }^{9}$ Elections are scheduled now for Sept. 27, 2015.
} 
space: The case of Spain. In B. Arthur, \& K. Felix (Eds.), Changing federal constitutions (Lessons from international comparisons) (pp. 190-209). Opladen, Barbara Budrich Publishers.

Cover, R. M. (1981). The uses of jurisdictional redundancy: Interest, ideology and innovation. William and Mary Law Review, 22(4), 639-682

Díaz Ricci, R. M. (2009). Relaciones Gubernamentales de Cooperación. Buenos Aires, Ediar.

Elazar, D. J. (1987). Exploring federalism. Tuscaloosa, University of Alabama Press.

Fernández Ferreres, G. (2005). La contribución del Tribunal Constitucional al Estado Autonómico. Madrid, Iustel.

García Morales, M. J., \& Marín Arbos, X. (2010). Intergovernmental relations in Spain. In R. Chattopadhyay, \& K. Nerenberg (Eds.), Dialogues on intergovernmental relations in federal systems (pp. 44-47). Ottawa, Forum of Federations.

Gardner, J. A. (2007). In search of sub-national Constitutionalism. Paper presented at Seventh Congress of the International Association of Constitutional Law, Athens, Greece, June 11-15.

Grosswald Curran, V. (2006). Comparative law and language. In M. Reinmann, \& R. Zimmermann (Eds.), The Oxford handbook of comparative law (pp. 675-707). Oxford, Oxford University Press.

Hamann, K. (1999). Federalist Institutions, Voting Behavior, and Party Systems in Spain? PUBLIUS, 29(1), Winter.

Joseph, J. E. (2006). Language and politics, Edinburgh, Edinburgh University Press.

López Aguilar, J. F. (2011). La sentencia más larga (Repercusiones de la STC 31/2010; política y jurisprudencia'). In 27 TEORIA Y REALIDAD CONSTITUCIONAL, UNED and Ramón Areces.

Major, J. C. (2013). On the prickly matter of language. In C. Liz (Ed.), What's up with Catalonia? (The causes which impel them to the separation) (pp. 85-88). Ashfield, Mass, Catalonia Press.

Peces-Barba Martínez, G. (1988). La Elaboración de la Constitución de 1978. Madrid, Centro de Estudios Constitucionales.

Pujol, J. (2011). Interview. In T. Strubell (Ed.), What Catalans want (Could Catalonia become Europe's next State) (pp. 54-59). Ashfield, Mass., Catalonia Press.

Rodríguez Zapatero, J. L. (2013). El Dilema (600 días de vértigo). Barcelona, Planeta.

Sánchez Agesta, L.(1980). Sistema Político de la Constitución Española de 1978. Madrid, Editora Nacional.

Solózabal Echavarría, J. L. (2011). La sentencia sobre el Estatuto de Cataluña: Una visión de conjunto. In 151 REVISTA DE ESTUDIOS POLITICOS, January/ March, Madrid.

Valdés, B. R. (2001). El Estado federal interminable. In G. de Cortazar (Ed.), El Estado de las autonomías en el siglo XXI: cierre o apertura indefinida. Papeles para el Análisis y los Estudios Sociales, no.66.

Villaverde Menéndez, I. (2012). La igualdad en la diversidad (Forma de Estado y derechos fundamentales). Madrid, Centro de Estudios Políticos y Constitucionales. 